\title{
Cracking Difficult Biliary Stones
}

\author{
Phonthep Angsuwatcharakon ${ }^{1,2}$ and Rungsun Rerknimitr ${ }^{2,3}$ \\ ${ }^{1}$ Department of Anatomy, Faculty of Medicine, Chulalongkorn University and King Chulalongkorn Memorial Hospital, Bangkok, \\ ${ }^{2}$ Division of Gastroenterology, Department of Medicine, Faculty of Medicine, Chulalongkorn University and King Chulalongkorn \\ Memorial Hospital, Bangkok, ${ }^{3}$ Center of Excellence for Innovation and Endoscopy in Gastrointestinal Oncology, Faculty of Medicine, \\ Chulalongkorn University, Bangkok, Thailand
}

Apart from difficult biliary cannulation, biliary stone removal is considered one of the hurdles in endoscopic retrograde cholangiopancreatography. Generally, simple common bile duct (CBD) stones can be removed either with an extraction balloon or a basket. However, there are difficult stones that cannot be removed using these standard methods. The most difficult stones are large $\mathrm{CBD}$ stones and impacted stones in a tapering CBD. A few decades ago, mechanical lithotripsy was usually required to manage these stones. At present, endoscopic papillary large balloon dilation (EPLBD) of the biliary orifice has become the gold standard for large CBD stones up to $1.5 \mathrm{~cm}$. EPLBD can reduce the procedural time by shortening the stone removal process. It can also save the cost of the devices, especially multiple baskets, used in mechanical lithotripsy. Unfortunately, very large CBD stones, stones impacted in a tapering $\mathrm{CBD}$, and some intrahepatic duct stones still require lithotripsy. Peroral cholangioscopy provides direct visualization of the stone, which helps the endoscopist perform a probe-based lithotripsy either with an electrohydraulic probe or a laser probe. This technique can facilitate the management of difficult CBD stones with a high success rate and save procedural time without significant technical complications. Clin Endosc 2021;54:660-668

Key Words: Electrohydraulic lithotripsy; Large bile duct stone; Laser lithotripsy; Mechanical lithotripsy; Per-oral cholangioscopy

\section{INTRODUCTON}

Since the introduction of endoscopic biliary sphincterotomy in $1974,{ }^{1,2}$ the management of bile duct stones has shifted from surgical bile duct exploration to an endoscopic approach. However, there is a $15 \%$ failure rate of bile duct stone removal with standard biliary sphincterotomy plus stone extraction with either a balloon, a basket catheter, or their combination. ${ }^{3}$ Stone factors (e.g., size, number, or shape), bile duct factors (e.g., associated stricture, narrowing, or angulation), and the relationship between the stone and the bile duct (e.g., impact-

\footnotetext{
Received: September 22, 2020 Revised: December 1, 2020

Accepted: December 12, 2020

Correspondence: Rungsun Rerknimitr

Division of Gastroenterology, Department of Medicine, Faculty of Medicine, Chulalongkorn University, 1873 Rama IV Road, Pathum Wan, Bangkok 10330, Thailand

Tel: +66-2-2564265, Fax: +66-2-2527839, E-mail: ercp@live.com

ORCID: https://orcid.org/0000-0001-6866-6886
}

(c) This is an Open Access article distributed under the terms of the Creative Commons Attribution Non-Commercial License (http://creativecommons.org/ licenses/by-nc/3.0) which permits unrestricted non-commercial use, distribution, and reproduction in any medium, provided the original work is properly cited. ed stone) influence the success of stone extraction. ${ }^{4}$ The two main principles to facilitate stone removal in this situation are expanding the stone passage and reducing the stone size. Endoscopic papillary large balloon dilation (EPLBD) with a balloon sized $\geq 12 \mathrm{~mm}$ (Fig. 1) can result in up to a $50 \%$ reduction in the need for mechanical lithotripsy (ML). ${ }^{5}$ Both the American Society for Gastrointestinal Endoscopy (ASGE) and the European Society of Gastrointestinal Endoscopy (ESGE) recommend the use of EPLBD when dealing with difficult biliary stones. ${ }^{4,6}$ Because of safety concerns, EPLBD is contraindicated in the presence of biliary strictures or significantly tapered bile ducts, and the selected balloon size should not exceed the bile duct diameter to reduce the risk of perforation. In addition, the risk of bleeding can be minimized by choosing an adequate balloon inflation time (approximately $60 \mathrm{sec}$ ) and avoiding a large sphincterotomy before performing sphincteroplasty ${ }^{7}$. Limited sphincterotomy is recommended before performing EPLBD. ${ }^{6,7}$ Notably, the anecdotal concern about the risk of post-endoscopic retrograde cholangiopancreatography (ERCP) pancreatitis after balloon sphincteroplasty has been cleared by a recent meta-analysis showing that EPLBD 

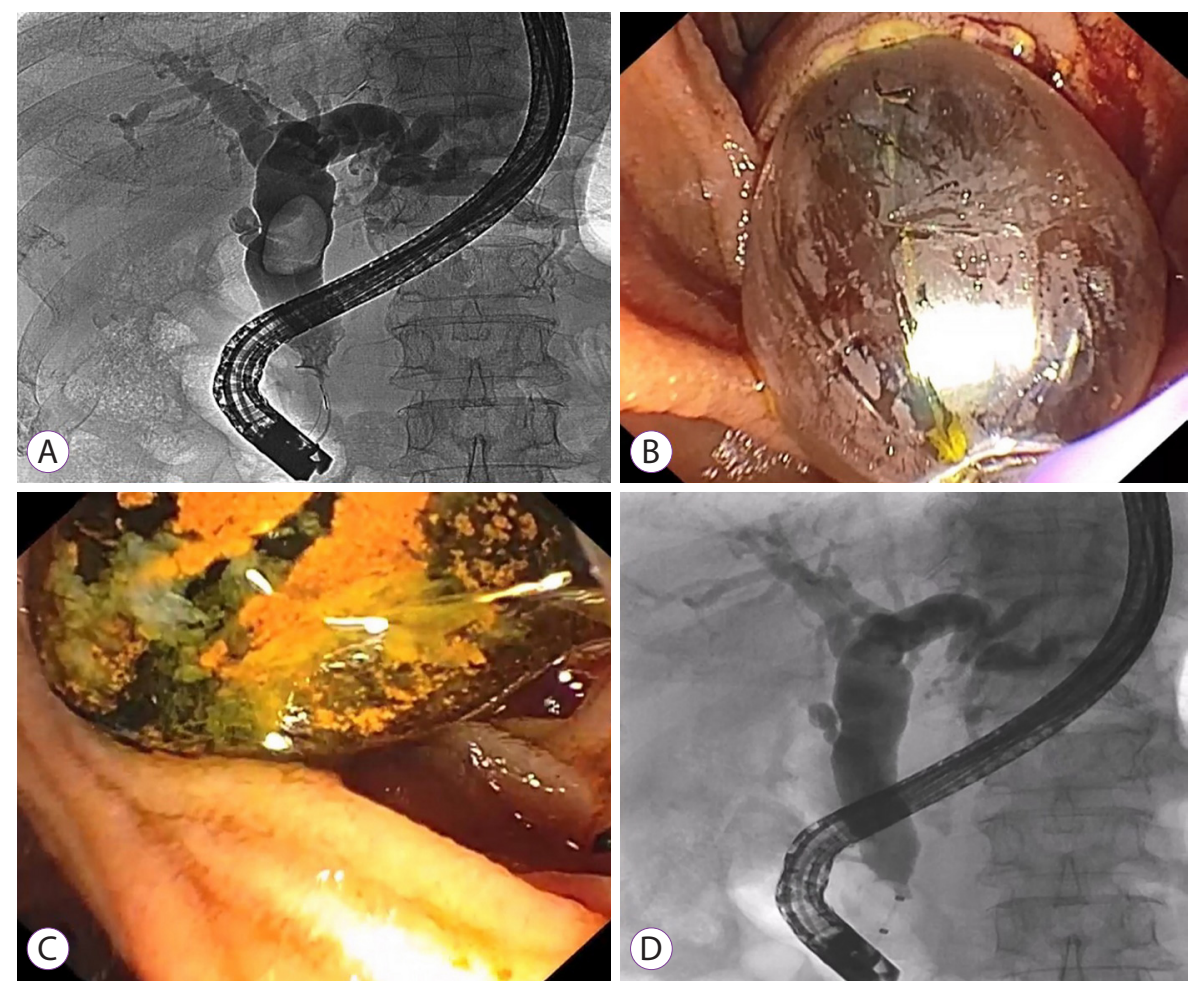

Fig. 1. A large bile duct stone successfully treated with endoscopic papillary large balloon dilation (EPLBD). (A) Cholangiogram showing a large bile duct stone. (B) Endoscopic view of EPLBD after sphincterotomy. (C) A large stone removed with an extraction balloon. (D) Occlusion cholangiogram showing no residual filling defect.

without prior sphincterotomy did not increase the risk of pancreatitis. $^{8}$

Despite the use of EPLBD, approximately 30\% of stone removal cases remain unsuccessful. .11 $^{91}$ Therefore, stone-cracking techniques are needed to reduce the stone size before standard stone removal. These techniques include ML, laser lithotripsy (LL), electrohydraulic lithotripsy (EHL), and extracorporeal shock-wave lithotripsy (ESWL). ML, LL, and EHL can be performed in an endoscopy suite; however, LL and EHL require direct visualization of the stone to precisely target and prevent bile duct injury. ESWL requires separate sessions of lithotripsy followed by ERCP for stone-fragment clearance. Practically, temporary biliary stenting is recommended as a bridge before complete stone removal. ${ }^{4}$

\section{MECHANICAL LITHOTRIPSY}

ML uses the shearing force between the basket wire and the metal sheath to crack the stone. The three main elements of a mechanical lithotripter are a basket, a traction wire, and a metal sheath. The stone is captured in the basket and crushed by tension applied to the traction wire. The basket can be used to remove stone fragments. ${ }^{12}$ There are two systems for metal sheath application. ${ }^{13}$ The first system is an extra-duodenoscope, in which the endoscope is removed after the stone is captured in the basket and the Teflon sheath of the basket is replaced by a metal sheath before lithotripsy. ${ }^{13}$ This system can rescue the trapped Dormia basket; therefore, it is also known as an emergency lithotripter. ${ }^{14}$ The second system is a self-contained through-the-scope mechanical lithotripter, in which the metal sheath can pass through the accessory channel of the endoscope (Fig. 2). After this system was introduced in 1982, ${ }^{15}$ ML has been commonly used for difficult stones, especially those $>15 \mathrm{~mm}$ or those that could not be removed with a balloon or a basket catheter after an endoscopic sphincterotomy. The overall success rate of ML ranges from $79 \%$ to $94 \%$, and the overall complication rate ranges from $3.3 \%$ to $17.6 \%{ }^{13,16-}$ ${ }^{21}$ However, the stone clearance rate in the first ML session ranges from $52.7 \%$ to $73.5 \%,{ }^{13,18-21}$ which means that up to half of the patients require more than one ERCP session. The main reasons for failed ML are (1) inability to capture the stone 

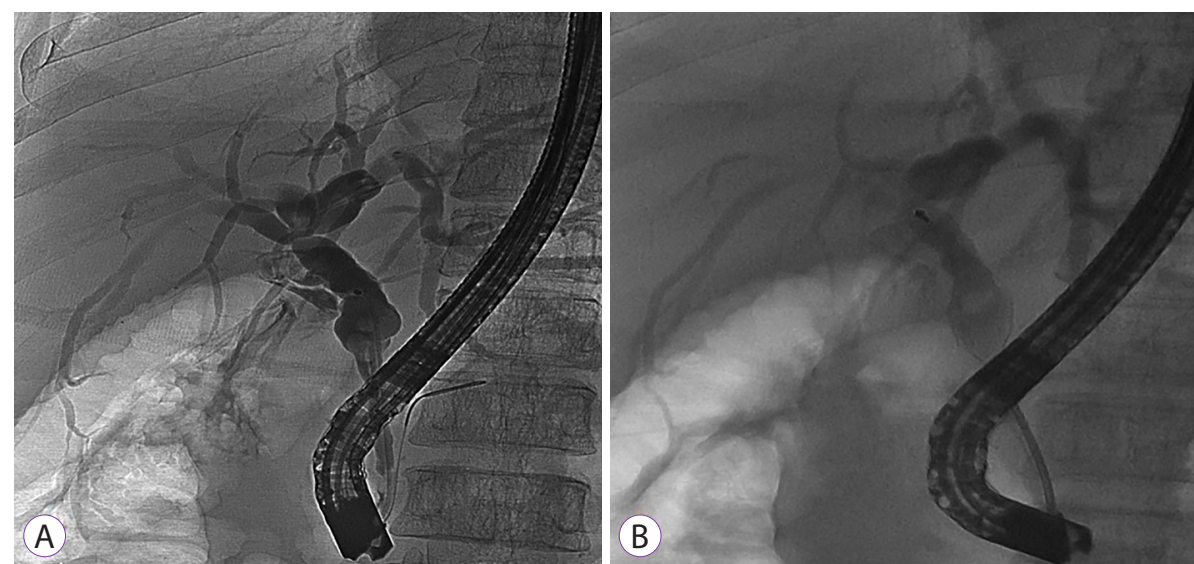

Fig. 2. Mechanical lithotripsy for a difficult bile duct stone. (A) A 1-cm stone proximal to a considerably tapered bile duct. (B) Mechanical lithotripsy was successfully performed using a through-the-scope mechanical lithotripter, and stone clearance was achieved.

because the stone size was too large, (2) inability to open the basket because the stone was impacted, and (3) biliary stricture (Table 1). Additionally, technical failures of ML, including a broken basket or a broken traction wire, have been reported to occur at a rate of $3.6 \%-6 \%{ }^{16,17,21,22}$

\section{CHOLANGIOSCOPY-GUIDED LITHOTRIPSY}

Endoscopic EHL and LL for bile duct stones were introduced in $1977^{23}$ and $1986,{ }^{24}$ respectively. However, the original version of the cholangioscope, the mother-baby cholangioscope, was considered a costly and cumbersome device. ${ }^{25} \mathrm{After}$ the development of single-operator cholangioscopy (SOC), ${ }^{26}$ EHL and LL have gained popularity. Direct visualization is necessary for both EHL and LL to precisely target the stones and prevent bile duct injury. The SOC scope can be inserted through the accessory channel of the duodenoscope. The EHL or LL probe can be inserted through the 1.2-mm channel and, more important, it can be operated by one endoscopist (Fig. 3). A recent meta-analysis of 35 studies (1,762 patients) demonstrated that cholangioscopy-guided intraductal lithotripsy for difficult biliary stones had an overall success rate of stone fragmentation of $91.2 \%$, with $76.9 \%$ complete stone clearance in a single session. Notably, the overall adverse event rate was 8.9\%. ${ }^{27}$ The subgroup analysis between EHL and LL found that there was no difference in the success rates of overall stone fragmentation ( $90.1 \%$ vs. $92.9 \%, p=0.360)$. However, EHL had a lower rate of complete stone clearance in a single ses- sion $(70.9 \%$ vs. $83 \%, p=0.021)$ and a longer mean procedure time (75.7 $\mathrm{min}$ vs. $54.3 \mathrm{~min}, p<0.001$ ) than $\mathrm{LL}^{27}$ Although the authors did not compare the types of cholangioscopes, the newer digital cholangioscope seemed to have a higher success rate and a lower complication rate than the original fiber-optic generation. The overall stone fragmentation success rates of the mother-baby cholangioscope, first-generation SOC scope, and second-generation SOC scope were $89.3 \%, 90.0 \%$, and $95.0 \%$, respectively. The rates of complete stone clearance in a single session were $66.8 \%, 80.6 \%$, and $80.4 \%$, respectively, and the overall adverse event rates were $13.5 \%, 9.8 \%$, and $4.1 \%$, respectively. ${ }^{27}$ Data from a large multinational registry demonstrated that a larger size of the largest stone and a higher number of stones had a negative impact on the rate of complete stone clearance in a single session. ${ }^{28}$

Cholangioscopy-guided lithotripsy is superior to other methods, including ML or EPLBD, because it can be used as a rescue method after the failure of ML or EPLBD, and is a good alternative to common bile duct (CBD) exploration. Buxbaum et al. reported that SOC-guided LL provided a higher stone clearance rate in $>10-\mathrm{mm}$ stones than the conventional methods, including ML and balloon sphincteroplasty (93\% vs. $67 \%$, $p=0.009$ ), in a randomized study. ${ }^{29}$ Another randomized control, non-inferiority study by Franzini et al. demonstrated that SOC-guided EHL had comparable outcomes to EPLBD with respect to the rate of complete stone clearance in a single session $(77.1 \%$ vs. $72 \%, p>0.05)$ and the adverse event rate $(4.2 \%$ vs. $12 \%, p>0.05) .{ }^{10}$ However, EPLBD had a significantly shorter procedural time than EHL (47.1 min vs. $72.3 \mathrm{~min}, p<0.05$ ). Interestingly, in the second session, which was performed us- 
Table 1. Outcome of Mechanical Lithotripsy for Difficult Bile Duct Stones

\begin{tabular}{|c|c|c|c|c|c|c|}
\hline $\begin{array}{l}\text { Study (num- } \\
\text { ber of pa- } \\
\text { tients) }\end{array}$ & Indication & $\begin{array}{l}\text { Type of mechani- } \\
\text { cal lithotripter }\end{array}$ & $\begin{array}{l}\text { Overall } \\
\text { success } \\
\text { rate }\end{array}$ & $\begin{array}{l}\text { First-ses- } \\
\text { sion suc- } \\
\text { cess rate }\end{array}$ & Reason of failed ML & Complications \\
\hline $\begin{array}{l}\text { Schneider et } \\
\text { al. }(1988)^{17} \\
(n=209)\end{array}$ & $\begin{array}{l}\text { Stone could not be re- } \\
\text { moved after EST with a } \\
\text { balloon or a basket }\end{array}$ & $\begin{array}{l}\text { Self-constructed } \\
\text { Erlangen litho- } \\
\text { tripter }\end{array}$ & $87.6 \%$ & $\mathrm{~N} / \mathrm{A}$ & $\begin{array}{l}\text { Mechanical failure }(n=26) \\
\text { - Inability to pass the } \\
\text { basket }(3 / 26) \\
\text { - Inability to capture the } \\
\text { stone }(23 / 26) \\
\text { Technical failure }(n=13) \\
\text { - Fracture of the basket } \\
\text { (9/13) } \\
\text { - Fracture of the traction } \\
\text { wire }(3 / 13) \\
\text { - Trapped lithotripter in } \\
\text { the scope }(1 / 13)\end{array}$ & $\begin{array}{l}\text { Bleeding }(2.9 \%) \text {, chol- } \\
\text { angitis }(0.5 \%)\end{array}$ \\
\hline $\begin{array}{l}\text { Siegel et al. } \\
(1990)^{13} \\
(n=93)\end{array}$ & $\begin{array}{l}\text { 1. Stone size exceeds the } \\
\text { maximum for sphinc- } \\
\text { terotomy } \\
\text { 2. Sphincterotomy contra- } \\
\text { indicated (e.g., bleeding } \\
\text { diathesis) with the stone } \\
\text { in the common bile } \\
\text { duct } \\
\text { 3. Narrowed distal com- } \\
\text { mon bile duct } \\
\text { 4. Distal stricture of the } \\
\text { bile duct with the stone } \\
\text { proximal to the stricture }\end{array}$ & $\begin{array}{l}\text { Through-the- } \\
\text { scope and ex- } \\
\text { tra-duodenoscope }\end{array}$ & $94 \%$ & $52.7 \%$ & N/A & $\begin{array}{l}\text { Bleeding }(5.4 \%), \\
\text { transient fever }(8.6 \%) \text {, } \\
\text { transient hyperamy- } \\
\text { lasemia }(6.5 \%)\end{array}$ \\
\hline $\begin{array}{l}\text { Chung et al. } \\
(1991)^{18} \\
(n=68)\end{array}$ & $\begin{array}{l}\text { Stone could not be re- } \\
\text { moved after EST with a } \\
\text { balloon or a basket }\end{array}$ & BML-1Q & $81 \%$ & $52.7 \%$ & $\begin{array}{l}\text { Mechanical failure }(n=13) \\
\text { - Failure to capture } \\
(13 / 13)\end{array}$ & $\begin{array}{l}\text { Perforation }(1.5 \%), \text { fa- } \\
\text { tal pancreatitis }(1.5 \%)\end{array}$ \\
\hline $\begin{array}{l}\text { Shaw et al. } \\
(1993)^{21} \\
(n=116)\end{array}$ & $\begin{array}{l}\text { Stone could not be re- } \\
\text { moved after EST with a } \\
\text { balloon or a basket }\end{array}$ & BML-3Q & $85 \%$ & $60 \%$ & $\begin{array}{l}\text { Mechanical failure }(n=6) \\
\text { - Failure to open }(2 / 6) \\
\text { - Failure to capture }(4 / 6) \\
\text { Technical failure }(n=4)\end{array}$ & $\begin{array}{l}\text { Immediate bleeding } \\
(4.3 \%) \text {, pancreatitis } \\
(1.7 \%) \text {, perforation } \\
(0.9 \%) \text {, cholangitis } \\
(1.7 \%)\end{array}$ \\
\hline $\begin{array}{l}\text { Cipolletta et } \\
\text { al. }(1997)^{19} \\
(n=162)\end{array}$ & $\begin{array}{l}\text { Stone could not be re- } \\
\text { moved after EST with a } \\
\text { balloon or a basket }\end{array}$ & $\begin{array}{l}\text { BML-1Q, BML- } \\
\text { 2Q, and BML-4Q }\end{array}$ & $84 \%$ & $73.5 \%$ & $\begin{array}{l}\text { Mechanical failure }(n=26) \\
\text { - Inability to capture the } \\
\text { stone }(24 / 26)\end{array}$ & $\begin{array}{l}\text { Cholangitis }(1.8 \%) \text {, } \\
\text { pancreatitis }(1.2 \%) \text {, } \\
\text { hyperamylasemia } \\
(22.2 \%)\end{array}$ \\
\hline $\begin{array}{l}\text { Garg et al. } \\
(2004)^{16} \\
(n=87)\end{array}$ & Stone $>15 \mathrm{~mm}$ & $\begin{array}{l}\text { BML-4Q, } \\
\text { Lithocrush } 201 \text { or } \\
\text { 202Q }\end{array}$ & $79 \%$ & $\mathrm{~N} / \mathrm{A}$ & $\begin{array}{l}\text { Mechanical failure }(n=15) \\
\text { - Failure to open and } \\
\text { capture }(15 / 15) \\
\text { Technical failure }(n=2) \\
\text { - Fracture of the basket } \\
(2 / 2) \\
\text { Bradycardia }(n=1)\end{array}$ & $\begin{array}{l}\text { Bleeding }(2.3 \%) \text {, } \\
\text { pancreatitis }(2.3 \%) \text {, } \\
\text { perforation }(1.1 \%)\end{array}$ \\
\hline $\begin{array}{l}\text { Chang et al. } \\
(2005)^{20} \\
(n=304)\end{array}$ & $\begin{array}{l}\text { Stone }>15 \mathrm{~mm} \text { or could } \\
\text { not be removed after EST } \\
\text { with a balloon or a basket }\end{array}$ & BML-4Q & $89.5 \%$ & $69 \%$ & $\begin{array}{l}\text { Mechanical failure }(n=27) \\
\text { - Failure to open or cap- } \\
\text { ture }(27 / 27) \\
\text { Biliary stricture }(n=5)\end{array}$ & $\begin{array}{l}\text { Cholangitis }(3.3 \%) \text {, } \\
\text { pancreatitis }(7 \%) \text {, de- } \\
\text { layed bleeding }(3.9 \%)\end{array}$ \\
\hline
\end{tabular}

EST, endoscopic sphincterotomy; ML, mechanical lithotripsy; N/A, not available. 


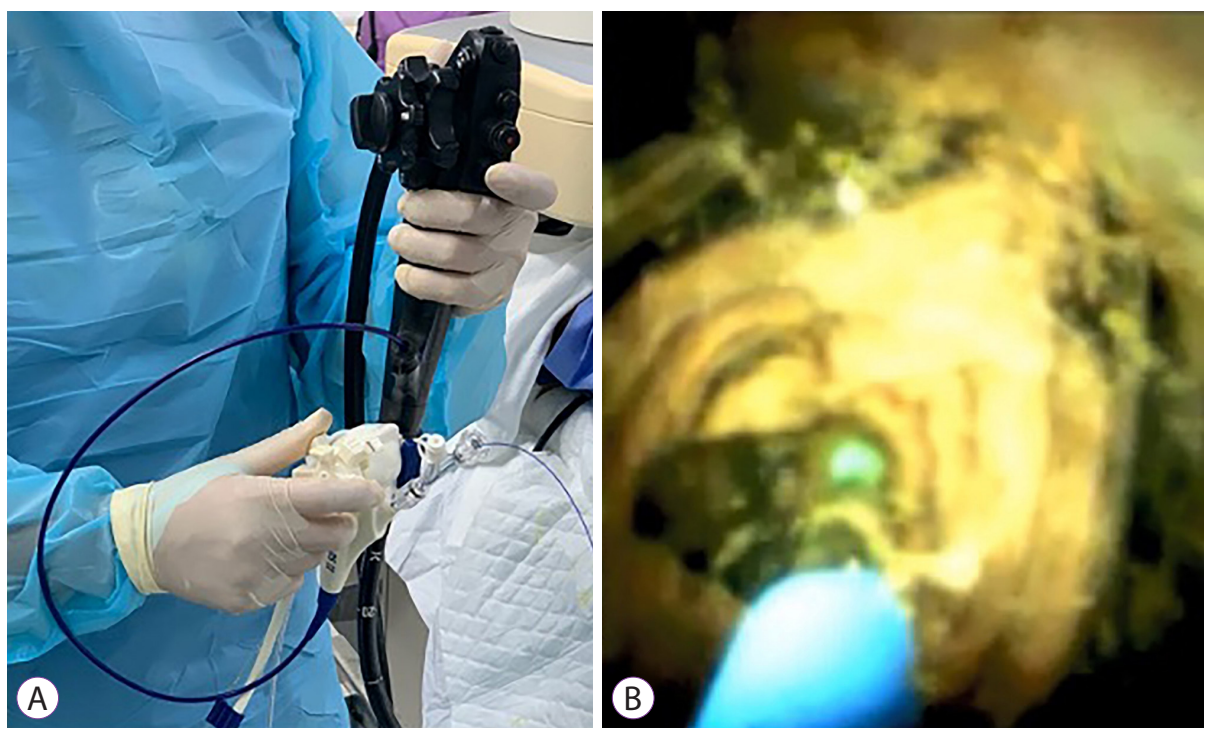

Fig. 3. Laser lithotripsy guided by single-operator cholangioscopy. (A) A disposable cholangioscope operated by a single endoscopist. The laser probe is inserted through the accessory channel of the cholangioscope, which is inserted through the accessory channel of the duodenoscope. (B) Cholangioscopic view of intraductal stone fragmentation with a laser probe.

ing a cross-over technique, EHL had a two times higher stone clearance rate than EPLBD. ${ }^{10}$ Another randomized controlled study by Bang et al. demonstrated that SOC-guided LL had a higher rate of complete stone clearance in a single session than EPLBD ( $93.9 \%$ vs. $72.7 \%, p=0.021)$, with comparable adverse event rate $(9.1 \%$ vs. $3 \%, p=0.61)$ and overall cost $(\$ 16,684$ vs. $\$ 10,626, p=0.097) .{ }^{11}$ A multiple logistic analysis revealed that single-session success was significantly associated with the use of LL, a stone-to-extrahepatic duct ratio of $\leq 1$, and the absence of a tapered bile duct, defined as a $<0.5$ ratio of the distal bile duct diameter (measured at $1 \mathrm{~cm}$ above the ampullary orifice) to the widest point in the proximal CBD. ${ }^{11}$ Furthermore, a randomized study by our group on huge stones with failed EPLBD demonstrated that SOC-guided LL was superior to $\mathrm{ML}$ in terms of having a higher rate of stone clearance in a single session $(100 \%$ vs. $63 \%, p<0.01)$ and a lower radiation exposure $\left(20,989 \mathrm{mGycm}^{2}\right.$ vs. $40,745 \mathrm{mGycm}^{2}$, $p=0.04$ ), whereas the adverse event rates were comparable (6\% vs. $13 \%, p=0.76) .{ }^{9}$ In addition, LL cleared all stones that ML failed to remove, and no surgery was needed in any patient. ${ }^{9}$ In a comparison with laparoscopic CBD exploration for $>20 \mathrm{~mm}$ CBD stones, SOC-guided LL had a lower stone clearance rate in a single session than surgery $(83.3 \%$ vs. $96.2 \%, p=0.023)$. However, the overall stone clearance rates $(92.3 \%$ vs. $96.2 \%, p=0.124)$ and overall adverse events $(5.1 \%$ vs. $10.1 \%, p=0.246)$ were comparable between the two proce- dures. Interestingly, patients who underwent SOC-guided LL had a shorter hospital stay ( 5.7 days vs. 8.8 days, $p=0.001$ ) and enhanced recovery, as determined by the postoperative gastrointestinal quality of life index at 1 and 3 months, than patients who underwent laparoscopic CBD exploration. ${ }^{30}$

Although the cost of disposable SOC scopes is relatively high, it could be a trade-off against multiple sessions of endoscopy (if the stones could not be cleared in a single session) and/or a longer hospital stay (if surgery is needed). A cost-effectiveness study from Belgium demonstrated that SOC-guided lithotripsy (either EHL or LL) reduced the overall expenditure for difficult bile duct stones when compared with ML. ${ }^{31}$

Direct peroral cholangioscopy (DPOC) is a procedure in which an ultra-slim upper endoscope is passed through the mouth into the bile duct without a side-viewing duodenoscope. This technique was first reported in $2007 .{ }^{32}$ Despite several adjunct accessories to assist bile duct insertion, such as a super-stiff guide wire, ${ }^{32}$ a balloon anchor, ${ }^{33}$ and a special overtube ${ }^{34}$ this technique is still not widely used because it is technically demanding. Recently, an ultra-slim endoscope (CHF-Y0010; Olympus Medical Systems, Co., Ltd., Tokyo, Japan; Fig. 4), a new prototype of DPOC with two bending sections in the distal end, two accessory channels (2.2- and 1-mm diameter), and a 4.9-mm-diameter (at the tip) scope, was evaluated. ${ }^{35}$ This multibending ultra-slim scope has a higher success rate of free-hand biliary insertion than the conventional 

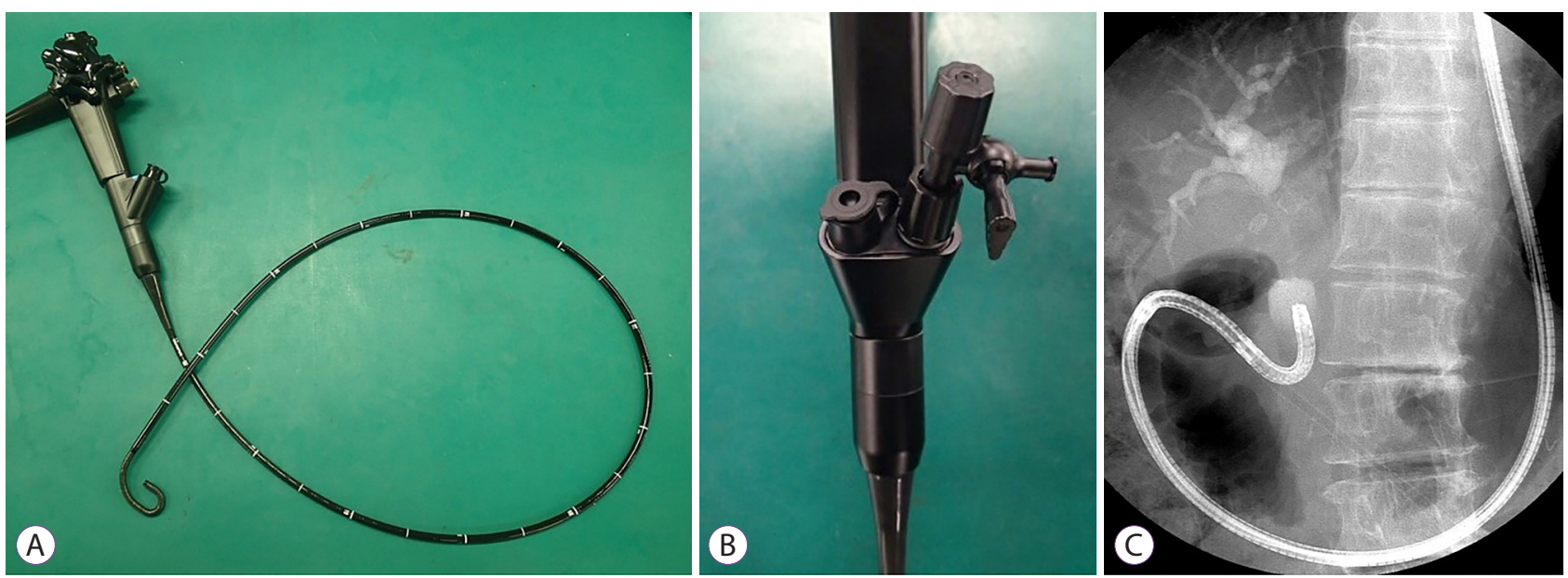

Fig. 4. Prototype of a mutibending ultra-slim scope. (A) The distal end has two bending sections for facilitating biliary insertion. (B) Two accessory channels (2.2 and $1 \mathrm{~mm}$ ) designed to facilitate irrigation during intraductal lithotripsy. (C) Free-hand bile duct insertion of the scope. (Picture courtesy of Prof. Jong H. Moon, MD, PhD, FASGE, FJGES, Director of Digestive Disease Center, SoonChunHyang University School of Medicine, Bucheon/Seoul, Korea).

ultra-slim scope ( $89.1 \%$ vs. $30.4 \%, p<0.001)$, with comparable adverse event rates $(6.5 \%$ vs. $4.3 \%, p=0.50) .{ }^{35}$ DPOC-guided lithotripsy was reported to have a high overall stone clearance rate of $84.6 \%-90 \%$, although the studies included a small number of patients. ${ }^{36-38}$ However, when performing endoscopy directly in the bile duct, special caution is needed to avoid air embolism, such as using $\mathrm{CO}_{2}$ insufflation instead of air insufflation. ${ }^{39,40}$

\section{EXTRACORPOREAL SHOCK-WAVE LITHOTRIPSY}

ESWL uses shock waves generated from electrohydraulic or electromagnetic energy. The shock waves are transmitted from outside the body through soft tissue to the target (bile duct stones) under fluoroscopy guidance. ${ }^{41}$ The first ESWL for the treatment of bile duct stones was reported in $1986 .{ }^{42}$ Thereafter, difficult stones that could not be removed with a standard ERCP became the most common indication of ESWL for bile duct stones. The overall stone clearance rate is $84.4 \%-$ $90.2 \%{ }^{43,44}$ Post-ESWL complications were reported in $9.1 \%-$ $15.9 \%,{ }^{22,44}$ and the most common complications were hemobilia $(12 \%)^{22}$ and cardiac arrhythmia (5.9\%). ${ }^{44}$ ESWL has several limitations. First, a nasobiliary tube or a T-tube is required to opacify the stone because most of the stones are radiolucent. Second, several sessions are needed to achieve a high stone clearance rate; for example, three sessions are required to achieve a stone clearance rate of $74 \%$. Third, epidural or gen- eral anesthesia is necessary during ESWL. ${ }^{43,44}$ A randomized study demonstrated that ESWL was inferior to intraductal LL in terms of complete stone clearance ( $73 \%$ vs. $97 \%, p<0.05)$, mean number of treatment sessions ( 3 vs. $1.2, p<0.001$ ), and mean duration of treatment (3.9 days vs. 0.9 days, $p<0.001$ ). ${ }^{45}$ The ESGE recommends ESWL when conventional lithotripsy fails and cholangioscopy-guided lithotripsy is not available. ${ }^{4}$

\section{BILIARY STENT PLACEMENT}

Placement of a temporary biliary plastic stent after ERCP is indicated when stone clearance is not achieved, to avoid stone impaction and prevent cholangitis and pancreatitis. ${ }^{4,4}$ In addition, it can decrease the stone size by causing friction between the stent and the stone, which can enhance the success rate of the subsequent ERCP. ${ }^{47,48}$ However, ERCP should be repeated within 3-6 months to avoid cholangitis. ${ }^{4,47}$ A long-term stent should be reserved for high-risk patients with a short life expectancy owing to the risk of recurrent cholangitis. ${ }^{46}$ The additional use of choleretic agents (i.e., ursodeoxycholic acid and terpene combination) showed no benefit on stone size reduction or stone clearance in a prospective study in 51 patients by Lee et al. ${ }^{49}$ After a fully covered self-expandable metal stent (FCSEMS) was placed in patients with incomplete stone clearance, the subsequent ERCP achieved complete stone clearance in $82 \%-83 \%$. The FCSEMS not only provides friction to reduce the size of the stone but also expands the bile duct orifice. However, the risk of stent migration is $9.5 \%-$ 


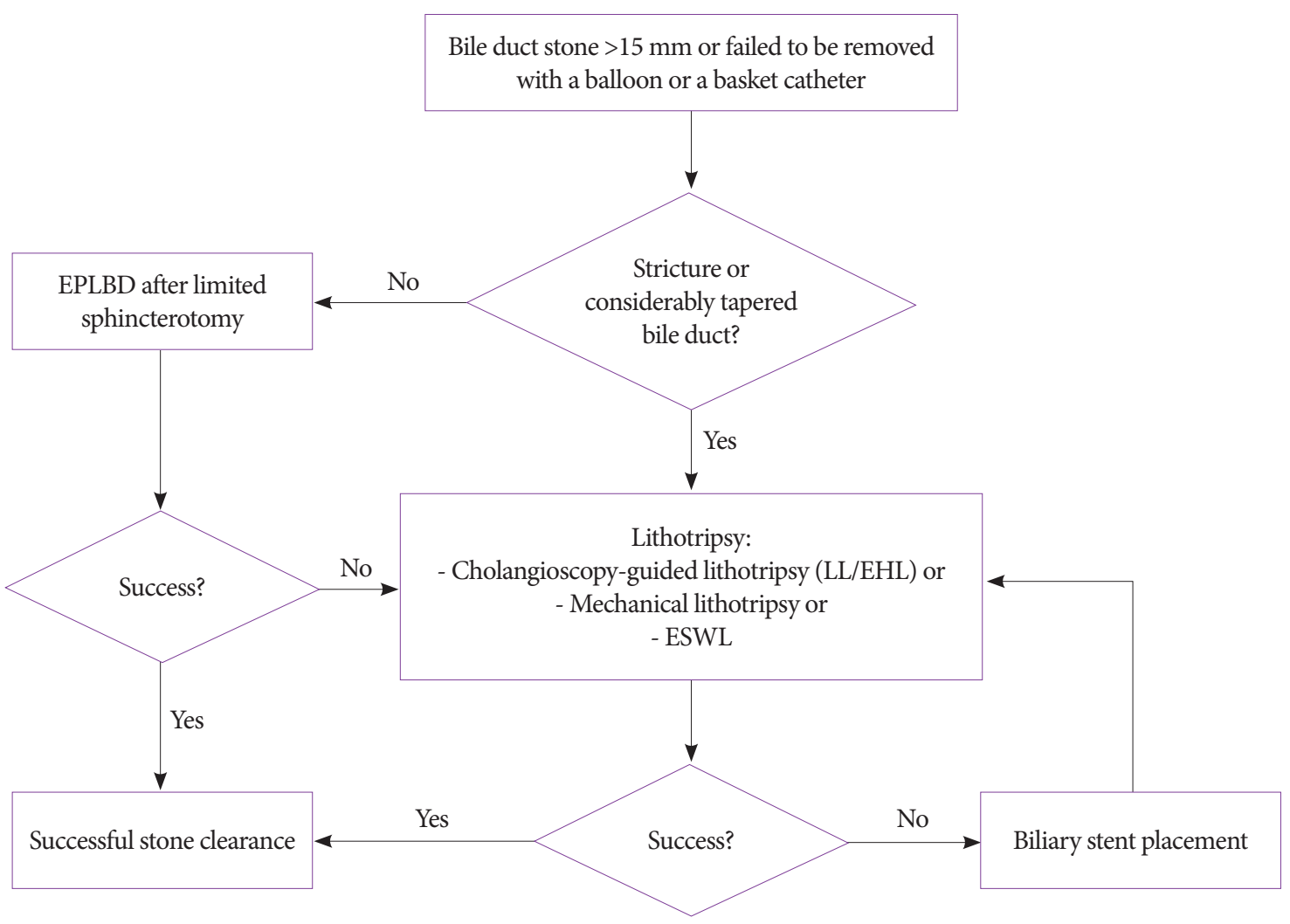

Fig. 5. Recommendation for the management of difficult bile duct stones.

$22 \%{ }^{50,51}$ Although the ESGE does not recommend the use of FCSEMS, ${ }^{4}$ the $\mathrm{ASGE}^{6}$ states that FCSEMS may facilitate the removal of difficult bile duct stones, but a subsequent stent exchange or removal is required. An in vitro study demonstrated that drug-eluting FCSEMS was able to reduce the stone mass. ${ }^{52}$ However, clinical studies on the benefits of drug-eluting FCSEMS are needed before applying this treatment in clinical practice.

\section{CONCLUSIONS}

EPLBD, with a balloon diameter that does not exceed the bile duct diameter after a limited sphincterotomy, is recommended as the first step for removing difficult stones where there is no contraindication. If EPLBD fails, either cholangioscopy-guided lithotripsy or ML can be chosen. However, cholangioscopy-guided lithotripsy has a higher success rate than ML. ESWL is an alternative when ML fails and cholangioscopy-guided lithotripsy is not available. Temporary biliary stenting is indicated when every technique has failed, or when the duration of the procedure has become too long but complete stone clearance is still not achieved during that session. An indefinite biliary stent is reserved only for patients with a short life expectancy (Fig. 5).

Conflicts of Interest

The authors have no potential conflicts of interest.

Funding

This article was funded by a grant for International Research Integration: Chula Research Scholar, Ratchadaphiseksomphot Endowment Fund and Center of Excellence for Innovation and Endoscopy in Gastrointestinal Oncology, Faculty of Medicine, Chulalongkorn University.

Acknowledgments

The authors sincerely thank Prof. Jong H. Moon, MD, PhD, FASGE, FJGES, Director of Digestive Disease Center, SoonChunHyang University School of Medicine, Bucheon/Seoul, Korea, for the image of the multibending ultra-slim scope prototype.

ORCID

Phonthep Angsuwatcharakon: https://orcid.org/0000-0001-6924-2794 Rungsun Rerknimitr: 


\section{REFERENCES}

1. Classen M, Demling L. [Endoscopic sphincterotomy of the papilla of vater and extraction of stones from the choledochal duct (author's transl)]. Dtsch Med Wochenschr 1974;99:496-497.

2. Kawai K, Akasaka Y, Murakami K, Tada M, Koli Y. Endoscopic sphincterotomy of the ampulla of Vater. Gastrointest Endosc 1974;20:148-151.

3. McHenry L, Lehman G. Difficult bile duct stones. Curr Treat Options Gastroenterol 2006;9:123-132.

4. Manes G, Paspatis G, Aabakken L, et al. Endoscopic management of common bile duct stones: European Society of Gastrointestinal Endoscopy (ESGE) guideline. Endoscopy 2019;51:472-491.

5. Madhoun MF, Wani S, Hong S, Tierney WM, Maple JT. Endoscopic papillary large balloon dilation reduces the need for mechanical lithotripsy in patients with large bile duct stones: a systematic review and meta-analysis. Diagn Ther Endosc 2014;2014:309618.

6. ASGE Standards of Practice Committee, Buxbaum JL, Abbas Fehmi SM, et al. ASGE guideline on the role of endoscopy in the evaluation and management of choledocholithiasis. Gastrointest Endosc 2019;89:10751105.e15.

7. Kim TH, Kim JH, Seo DW, et al. International consensus guidelines for endoscopic papillary large-balloon dilation. Gastrointest Endosc 2016;83:37-47.

8. Matsubayashi CO, Ribeiro IB, de Moura DTH, et al. Is endoscopic balloon dilation still associated with higher rates of pancreatitis?: a systematic review and meta-analysis. Pancreas 2020;49:158-174.

9. Angsuwatcharakon P, Kulpatcharapong S, Ridtitid W, et al. Digital cholangioscopy-guided laser versus mechanical lithotripsy for large bile duct stone removal after failed papillary large-balloon dilation: a randomized study. Endoscopy 2019;51:1066-1073.

10. Franzini T, Moura RN, Bonifácio P, et al. Complex biliary stones management: cholangioscopy versus papillary large balloon dilation - a randomized controlled trial. Endosc Int Open 2018;6:E131-E138.

11. Bang JY, Sutton B, Navaneethan U, Hawes R, Varadarajulu S. Efficacy of single-operator cholangioscopy-guided lithotripsy compared with large balloon sphincteroplasty in management of difficult bile duct stones in a randomized trial. Clin Gastroenterol Hepatol 2020;18:2349-2356.e3.

12. Demling L, Seuberth K, Riemann JF. A mechanical lithotripter. Endoscopy 1982;14:100-101.

13. Siegel JH, Ben-Zvi JS, Pullano WE. Mechanical lithotripsy of common duct stones. Gastrointest Endosc 1990;36:351-356.

14. Schutz SM, Chinea C, Friedrichs P. Successful endoscopic removal of a severed, impacted Dormia basket. Am J Gastroenterol 1997;92:679-681.

15. Riemann JF, Seuberth K, Demling L. Clinical application of a new mechanical lithotripter for smashing common bile duct stones. Endoscopy 1982;14:226-230.

16. Garg PK, Tandon RK, Ahuja V, Makharia GK, Batra Y. Predictors of unsuccessful mechanical lithotripsy and endoscopic clearance of large bile duct stones. Gastrointest Endosc 2004;59:601-605.

17. Schneider MU, Matek W, Bauer R, Domschke W. Mechanical lithotripsy of bile duct stones in 209 patients--effect of technical advances. Endoscopy 1988;20:248-253.

18. Chung SC, Leung JW, Leong HT, Li AK. Mechanical lithotripsy of large common bile duct stones using a basket. Br J Surg 1991;78:1448-1450.

19. Cipolletta L, Costamagna G, Bianco MA, et al. Endoscopic mechanical lithotripsy of difficult common bile duct stones. Br J Surg 1997;84:14071409.

20. Chang WH, Chu CH, Wang TE, Chen MJ, Lin CC. Outcome of simple use of mechanical lithotripsy of difficult common bile duct stones. World J Gastroenterol 2005;11:593-596.

21. Shaw MJ, Mackie RD, Moore JP, et al. Results of a multicenter trial using a mechanical lithotripter for the treatment of large bile duct stones. Am J Gastroenterol 1993;88:730-733.

22. Thomas M, Howell DA, Carr-Locke D, et al. Mechanical lithotripsy of pancreatic and biliary stones: complications and available treatment options collected from expert centers. Am J Gastroenterol 2007;102:18961902.

23. Koch H, Stolte M, Walz V. Endoscopic lithotripsy in the common bile duct. Endoscopy 1977;9:95-98.

24. Lux G, Ell C, Hochberger J, Müller D, Demling L. The first successful endoscopic retrograde laser lithotripsy of common bile duct stones in man using a pulsed neodymium-YAG laser. Endoscopy 1986;18:144145.

25. Shim CS, Neuhaus H, Tamada K. Direct cholangioscopy. Endoscopy 2003;35:752-758

26. Chen YK, Pleskow DK. SpyGlass single-operator peroral cholangiopancreatoscopy system for the diagnosis and therapy of bile-duct disorders: a clinical feasibility study (with video). Gastrointest Endosc 2007;65:832841.

27. McCarty TR, Gulati R, Rustagi T. Efficacy and safety of peroral cholangioscopy with intraductal lithotripsy for difficult biliary stones: a systematic review and meta-analysis. Endoscopy 2021;53:110-122.

28. Maydeo AP, Rerknimitr R, Lau JY, et al. Cholangioscopy-guided lithotripsy for difficult bile duct stone clearance in a single session of ERCP: results from a large multinational registry demonstrate high success rates. Endoscopy 2019;51:922-929.

29. Buxbaum J, Sahakian A, Ko C, et al. Randomized trial of cholangioscopy-guided laser lithotripsy versus conventional therapy for large bile duct stones (with videos). Gastrointest Endosc 2018;87:1050-1060.

30. Li G, Pang Q, Zhai H, et al. SpyGlass-guided laser lithotripsy versus laparoscopic common bile duct exploration for large common bile duct stones: a non-inferiority trial. Surg Endosc 2021;35:3723-3731.

31. Deprez PH, Garces Duran R, Moreels T, et al. The economic impact of using single-operator cholangioscopy for the treatment of difficult bile duct stones and diagnosis of indeterminate bile duct strictures. Endoscopy 2018;50:109-118.

32. Larghi A, Waxman I. Endoscopic direct cholangioscopy by using an ultra-slim upper endoscope: a feasibility study. Gastrointest Endosc 2006;63:853-857.

33. Moon JH, Ko BM, Choi HJ, et al. Intraductal balloon-guided direct peroral cholangioscopy with an ultraslim upper endoscope (with videos). Gastrointest Endosc 2009;70:297-302.

34. Choi HJ, Moon JH, Ko BM, et al. Overtube-balloon-assisted direct peroral cholangioscopy by using an ultra-slim upper endoscope (with videos). Gastrointest Endosc 2009;69:935-940.

35. Lee YN, Moon JH, Lee TH, et al. Prospective randomized trial of a new multibending versus conventional ultra-slim endoscope for peroral cholangioscopy without device or endoscope assistance (with video). Gastrointest Endosc 2020;91:92-101.

36. Kim HI, Moon JH, Choi HJ, et al. Holmium laser lithotripsy under direct peroral cholangioscopy by using an ultra-slim upper endoscope for patients with retained bile duct stones (with video). Gastrointest Endosc 2011;74:1127-1132.

37. Moon JH, Ko BM, Choi HJ, et al. Direct peroral cholangioscopy using an ultra-slim upper endoscope for the treatment of retained bile duct stones. Am J Gastroenterol 2009;104:2729-2733.

38. Lee TY, Cheon YK, Choe WH, Shim CS. Direct cholangioscopy-based holmium laser lithotripsy of difficult bile duct stones by using an ultrathin upper endoscope without a separate biliary irrigating catheter. Photomed Laser Surg 2012;30:31-36.

39. Paramasivam RK, Angsuwatcharakon P, Soontornmanokul T, Rerknimitr R. Management of endoscopic complications, in particular perforation. Dig Endosc 2013;25 Suppl 2:132-136.

40. Efthymiou M, Raftopoulos S, Antonio Chirinos J, May GR. Air embolism complicated by left hemiparesis after direct cholangioscopy with an intraductal balloon anchoring system. Gastrointest Endosc 2012;75:221223.

41. Bland KI, Jones RS, Maher JW, et al. Extracorporeal shock-wave litho- 
tripsy of bile duct calculi. An interim report of the Dornier U.S. bile duct lithotripsy prospective study. Ann Surg 1989;209:743-753; discussion 753-755.

42. Sauerbruch T, Delius M, Paumgartner G, et al. Fragmentation of gallstones by extracorporeal shock waves. N Engl J Med 1986;314:818-822.

43. Tandan M, Reddy DN, Santosh D, et al. Extracorporeal shock wave lithotripsy of large difficult common bile duct stones: efficacy and analysis of factors that favor stone fragmentation. J Gastroenterol Hepatol 2009;24:1370-1374.

44. Amplatz S, Piazzi L, Felder M, et al. Extracorporeal shock wave lithotripsy for clearance of refractory bile duct stones. Dig Liver Dis 2007;39:267272.

45. Neuhaus H, Zillinger C, Born P, et al. Randomized study of intracorporeal laser lithotripsy versus extracorporeal shock-wave lithotripsy for difficult bile duct stones. Gastrointest Endosc 1998;47:327-334.

46. Chopra KB, Peters RA, O'Toole PA, et al. Randomised study of endoscopic biliary endoprosthesis versus duct clearance for bileduct stones in high-risk patients. Lancet 1996;348:791-793.

47. Di Giorgio P, Manes G, Grimaldi E, et al. Endoscopic plastic stenting for bile duct stones: stent changing on demand or every 3 months. A prospective comparison study. Endoscopy 2013;45:1014-1017.

48. Jang DK, Lee SH, Ahn DW, et al. Factors associated with complete clearance of difficult common bile duct stones after temporary biliary stenting followed by a second ERCP: a multicenter, retrospective, cohort study. Endoscopy 2020;52:462-468.

49. Lee TH, Han JH, Kim HJ, Park SM, Park SH, Kim SJ. Is the addition of choleretic agents in multiple double-pigtail biliary stents effective for difficult common bile duct stones in elderly patients? A prospective, multicenter study. Gastrointest Endosc 2011;74:96-102.

50. Hartery K, Lee CS, Doherty GA, et al. Covered self-expanding metal stents for the management of common bile duct stones. Gastrointest Endosc 2017;85:181-186.

51. Cerefice M, Sauer B, Javaid M, et al. Complex biliary stones: treatment with removable self-expandable metal stents: a new approach (with videos). Gastrointest Endosc 2011;74:520-526.

52. Huang C, Cai XB, Guo LL, Qi XS, Gao Q, Wan XJ. Drug-eluting fully covered self-expanding metal stent for dissolution of bile duct stones in vitro. World J Gastroenterol 2019;25:3370-3379. 